\title{
PENGARUH SUBSTITUSI TEPUNG TERIGU DENGAN TEPUNG RUMPUT LAUT SARGASSUM SP TERHADAP KANDUNGAN ZAT GIZI DAN KESUKAAN MP-ASI BISKUIT KAYA ZAT BESI
}

\author{
Nina Sakinah, Fitriyono Ayustaningwarno*) \\ Program Studi Ilmu Gizi Fakultas Kedokteran Universitas Diponegoro \\ Jl.Dr.Sutomo No.14, Semarang, Telp (024) 8453708, Email : gizifk@undip.ac.id
}

\begin{abstract}
Background : Iron deficiency anemia affects 43\% of 12-24 months old children population in the world. One of the factor cause is lack of high intake of iron. Iron enrichment can be done by using local food such as seaweed Sargassum sp which has high bioavailability iron on biscuit product that appropriate with 12-24 months old children.

Objective : Analyze the effect of seaweed Sargassum sp flour substitution on the nutrient content such us iron, protein, carbohydrat, fat, crude fiber, ash, and water also preference such us color, aroma, taste and texture of children's biscuit.

Method : One factor completely randomized experimental study which used 5 substitution level of seaweed Sargassum sp flour which are 100:0, 90:10, 85:15, 80:20, 75:25. Statistic analysis of nutrient content use One Way ANOVA CI 95\% followed by Tukey and LSD Posthoc test. Preference content analysis use Friedman followed by Wilcoxon sign rank test CI $95 \%$.

Result : Seaweed Sargassum sp flour substitution variation on children biscuit increase iron content. Biscuit with highest iron content is biscuit with $25 \%$ substitution. Substitution of seaweed Sargassum sp flour sigfinicantly influence crude fiber, and ash also preference include color, aroma, taste and texture but do not significantly influence fat, carbohydrat, protein and water.

Conclusion : Substitution of seaweed Sargassum sp flour sigfinicantly influence iron, crude fiber, and ash content also preference include color, aroma, taste and texture but do not influence fat, carbohydrat, protein and water content.
\end{abstract}

Keyword : iron deficiency anemia; nutrient content; biscuit; Sargassum sp flour

\begin{abstract}
ABSTRAK
Latar Belakang : Anemia defisiensi zat besi berpengaruh pada 43\% anak usia 12-24 bulan di dunia. Salah satu faktor penyebab adalah kurangnya asupan tinggi zat besi. Pengkayaan kandungan zat besi dapat dilakukan dengan memanfaatkan bahan pangan lokal seperti rumput laut Sargassum sp yang memiliki kandungan zat besi dengan bioavailabilitas tinggi pada (Makanan Pendamping Air Susu Ibu) MP-ASI biskuit sebagai produk yang sesuai dengan anak usia 12-24 bulan.

Tujuan : Menganalisis pengaruh variasi substitusi tepung rumput laut terhadap kandungan gizi meliputi zat besi, protein, karbohidrat, lemak, serat kasar, air dan abu serta kesukaan yang meliputi warna, aroma, rasa dan tekstur MP-ASI biskuit.

Metode : Merupakan penelitian eksperimental rancangan acak lengkap satu faktor dengan 5 taraf perlakuan. Variasi perlakuan tepung terigu dengan tepung rumput laut Sargassum sp adalah 100:0, 90:10,85:15, 80:20, 75:25. Analisis statistik kandungan gizi menggunakan uji One Way ANOVA CI 95\% dilanjutkan Posthoc test Tukey dan LSD. Analisis statistik kesukaan menggunakan uji Friedman dilanjutkan uji Wilcoxon sign rank test CI 95\%.

Hasil : Variasi substitusi tepung rumput laut Sargassum sp pada MP-ASI biskuit berpengaruh terhadap peningkatan kadar zat besi. Kadar zat besi tertinggi terdapat pada MP-ASI biskuit dengan substitusi tepung rumput laut 25\%. Substitusi tepung rumput laut Sargassum sp berpengaruh pada kadar zat besi serat kasar, dan abu, serta kesukaan meliputi warna, aroma, rasa, dan tekstur namun tidak berpengaruh terhadap kadar protein, lemak, karbohidrat dan air.

Kesimpulan : Substitusi tepung rumput laut Sargassum sp berpengaruh terhadap kadar zat besi, serat kasar, abu serta kesukaan meliputi warna, aroma, rasa, dan tekstur MP-ASI biskuit, namun tidak berpengaruh terhadap kadar protein, lemak, karbohidrat dan air.
\end{abstract}

Kata kunci : Anemia defisiensi besi; kandungan zat gizi; MP-ASI biskuit; tepung Sargassum sp

\footnotetext{
${ }^{*}$ Penulis Penanggungjawab
} 


\section{PENDAHULUAN}

Anak-anak merupakan salah satu kelompok usia yang rentan terhadap kejadian anemia. ${ }^{1}$ Pada anak-anak terutama di negara berkembang, sekitar 300 juta anak usia 12-24 bulan mengalami anemia dan hampir 50\% kasus anemia yang terjadi merupakan anemia defisiensi zat besi. ${ }^{2}$ Prevalensi anemia defisiensi zat besi di dunia pada anak usia 12-24 bulan adalah sebesar 43\%. ${ }^{1}$ Salah satu faktor penyebab anemia defisiensi zat besi pada anak adalah kurangnya asupan makanan tinggi zat besi, sementara kebutuhan akan zat besi relatif tinggi pada masa pertumbuhan. $^{3}$ Alternatif yang dapat dilakukan dalam mengatasi masalah tersebut adalah dengan meningkatkan asupan yang dibutuhkan untuk dapat memenuhi kecukupan zat besi pada anak. Salah satu makanan yang dapat dikonsumsi oleh anakanak usia 12-24 bulan sebagai Makanan Pendamping Air Susu Ibu (MP-ASI) adalah biskuit. ${ }^{4}$ Berdasarkan ketetapan Departemen Kesehatan RI, persyaratan untuk kandungan zat gizi MP-ASI biskuit harus terpenuhi energi minimum $400 \mathrm{kkal} / 100 \mathrm{~g}$ dan zat besi $5 \mathrm{mg} / 100 \mathrm{~g}$.

Pengkayaan kandungan zat besi dapat dilakukan dengan memanfaatkan bahan pangan lokal seperti rumput laut. Produksi rumput laut di Indonesia pada tahun 2010 adalah 3,082 juta ton meningkat dibandingkan pada tahun 2009 yakni sebesar 2,574 juta ton. ${ }^{5}$ Jenis rumput laut yang memiliki kandungan zat besi dengan bioavailabilitas yang tinggi adalah Sargassum $S p$. Kadar zat besi rumput laut Sargassum $s p$ sebesar $68,2 \mathrm{mg} / 100 \mathrm{~g}$ berat kering $^{7}$, dengan bioavailabilitas sebesar $22 \%$. Persentase dalam Sargassum $s p$ lebih besar karena tidak ditemukan kandungan asam fitat didalamnya ${ }^{8}$ jika dibandingkan dengan sumber zat besi non heme lain seperti yang ada pada sayur yaitu maksimum $10 \%$ persentasenya pun lebih besar. ${ }^{9}$

Berdasarkan latar belakang tersebut maka akan dilakukan penelitian mengenai pengaruh substitusi tepung terigu dengan tepung rumput laut Sargassum sp terhadap kandungan zat gizi serta nilai kesukaan MP-ASI biskuit, sehingga diharapkan dapat dimanfaatkan sebagai alternatif makanan untuk mencukupi kebutuhan zat gizi terutama zat besi pada anak usia 12-24 bulan.

\section{METODE}

Penelitian yang dilakukan merupakan penelitian dalam bidang ilmu food prduction, yang dilaksanakan pada bulan Juli hingga Agustus 2012 di Laboratorium Teknologi Pangan Jurusan Gizi
Fakultas Ilmu Kesehatan Universitas Muhammadiyah Semarang dan di Laboratorium Ilmu Pangan Fakultas Teknologi Pertanian Universitas Katolik Soegijapranata Semarang.

Penelitian ini termasuk penelitian eksperimental dengan rancangan acak lengkap satu faktor yakni persentase substitusi tepung rumput laut Sargassum $s p$ terhadap tepung terigu pada produk MP-ASI biskuit. Formula substitusi tepung terigu dengan tepung rumput laut Sargassum $s p$ dilakukan lima taraf perlakuan yaitu 100:0, 90:10, 85:15, 80:20 dan 75:25 dimana setiap perlakuan dilakukan tiga kali pengulangan. Penetapan formulasi didasarkan pada hasil analisis zat gizi bahan-bahan baku pembuatan biskuit dibandingkan dengan persyaratan kandungan energi dan kandungan zat gizi yang ada pada biskuit seperti kadar serat dan kadar zat besi menggunakan program software NutriSurvey for Windows 2005. Penelitian utama meliputi pembuatan MP-ASI biskuit dengan substitusi tepung rumput laut Sargassum $s p$, uji kandungan zat gizi dan uji kesukaan.

Bahan utama yang digunakan dalam pembuatan MP-ASI biskuit ini adalah tepung terigu dengan substitusi tepung rumput laut Sargassum $s p$. Rumput laut Sargassum $s p$ yang digunakan berasal dari perairan pesisir pantai Jepara, sementara tepung terigu yang digunakan merupakan jenis tepung terigu berprotein rendah. Bahan-bahan pendukung lain yang digunakan meliputi kuning telur, margarin, gula halus, vanili, dan baking powder. Sebelum pembuatan biskuit, diawali dengan proses penepungan rumput laut Sargassum $s p$ yang bisa dilihat pada Lampiran 1, kemudian dilanjutkan dengan proses pembuatan biskuit. Proses pembuatan biskuit dapat dilihat pada Lampiran 2.

Data yang dikumpulkan pada penelitian ini adalah variabel terikat diantaranya data kandungan zat gizi dan data kesukaan. Kandungan zat gizi yang dianalisis adalah kadar protein diperoleh dengan metode kjeldahl, ${ }^{12}$ lemak diperoleh dengan metode soxhlet, ${ }^{12}$ kadar air dengan metode oven ${ }^{12}$, kadar abu dengan metode drying $a s h^{12}$ dan karbohidrat diperoleh dengan perhitungan by different, ${ }^{12}$ serat kasar dengan metode gravimetri ${ }^{12}$ dan zat besi dengan metode Spektofometri Serapan Atom (SSA), ${ }^{12}$ penilaian kesukaan meliputi penilaian terhadap warna, aroma, rasa dan tekstur dari MP-ASI biskuit menggunakan uji hedonik dengan 5 skala kesukaan. ${ }^{13}$ Penilaian dilakukan tiga kali, pada 25 panelis agak terlatih yaitu mahasiswa Program 
Studi Ilmu Gizi Fakultas Kedokteran Universitas Diponegoro.

Data yang terkumpul dianalisis menggunakan program SPSS 16.0 for Windows. Pengaruh variasi persentase substitusi tepung rumput laut Sargassum $s p$ terhadap kandungan zat gizi diuji menggunakan One Way ANOVA dengan derajat kepercayaan $95 \%$ yang dilanjutkan dengan posthoc test Tukey untuk kadar zat besi dan LSD (Least Significance Different) untuk kadar abu, untuk mengetahui beda nyata perlakuan, sementara daya terima diuji menggunakan Friedman dengan derajat kepercayaan $95 \%$ yang dilanjutkan dengan posthoc test Wilcoxon untuk mengetahui beda nyata perlakuan.

\section{HASIL}

\section{A. Kandungan Zat Gizi MP-ASI biskuit}

Hasil analisis kandungan zat gizi dapat dilihat pada Lampiran 5 dan secara singkat dapat dilihat pada Tabel 1. Kadar zat besi MP-ASI biskuit berkisar antara 7,28 - 50,93 ppm. Hasil analisis menunjukkan terdapat pengaruh yang signifikan terhadap kadar zat besi MP-ASI biskuit dengan substitusi tepung rumput laut Sargassum $s p$ $(\mathrm{p}=0,000)$.

Kadar protein MP-ASI biskuit dengan substitusi tepung rumput laut Sargassum $s p$ berkisar antara 4,23 - 4,76\%. Formulasi tepung rumput laut Sargassum $s p$ sebagai substitusi pembuatan MP-ASI biskuit tidak berpengaruh terhadap kadar protein yang ada di dalam MP-ASI biskuit $(\mathrm{p}=0,882)$.

Kadar karbohidrat MP-ASI biskuit dengan substitusi tepung rumput laut Sargassum $s p$ berkisar antara $62,43-65,35 \%$. Formulasi tepung rumput laut Sargassum sp sebagai substitusi pembuatan MP-ASI biskuit tidak berpengaruh terhadap kadar karbohidrat MP-ASI biskuit $(\mathrm{p}=0,360)$.

Tabel 1. Hasil Analisis Kandungan Zat Gizi MP-ASI biskuit

\begin{tabular}{|c|c|c|c|c|c|c|c|}
\hline \multirow[b]{2}{*}{$\begin{array}{l}\text { Formul } \\
\text { a }\end{array}$} & \multicolumn{7}{|c|}{ Rerata Kandungan Zat gizi } \\
\hline & $\begin{array}{l}\text { Protein } \\
(\%)\end{array}$ & $\begin{array}{l}\text { Lemak } \\
(\%)\end{array}$ & $\begin{array}{l}\text { Karbohidr } \\
\text { at }(\%)\end{array}$ & $\begin{array}{l}\text { Serat } \\
\text { Kasar }(\%)\end{array}$ & $\begin{array}{l}\text { Zat besi } \\
(\mathrm{ppm})\end{array}$ & Air $(\%)$ & Abu (\%) \\
\hline TRL0\% & $\begin{array}{l}4,34 \pm 0,7 \\
4\end{array}$ & $\begin{array}{l}26,67 \pm 1,3 \\
7\end{array}$ & $\begin{array}{l}63,40 \pm 1,5 \\
2\end{array}$ & $5,04 \pm 0,61^{\mathrm{a}}$ & $7,82 \pm 2,40^{\mathrm{a}}$ & $\begin{array}{l}4,07 \pm 0,7 \\
1\end{array}$ & $\begin{array}{l}1,99 \pm 0,3 \\
3^{\mathrm{a}}\end{array}$ \\
\hline $\begin{array}{l}\text { TRL10 } \\
\%\end{array}$ & $\begin{array}{l}4,44 \pm 0,6 \\
2\end{array}$ & $\begin{array}{l}23,67 \pm 0,5 \\
5\end{array}$ & $\begin{array}{l}65,35 \pm 0,3 \\
1\end{array}$ & $\underset{b}{6,45 \pm 0,66^{\mathrm{a}}}$ & $\begin{array}{l}25,94 \pm 5,5 \\
5^{b}\end{array}$ & $\begin{array}{l}4,00 \pm 0,7 \\
7\end{array}$ & $\underset{b}{2,51 \pm 0,06^{\mathrm{a}}}$ \\
\hline $\begin{array}{l}\text { TRL15 } \\
\%\end{array}$ & $\begin{array}{l}4,52 \pm 0,4 \\
0\end{array}$ & $\begin{array}{l}26,18 \pm 0,5 \\
2\end{array}$ & $\begin{array}{l}62,43 \pm 0,7 \\
4\end{array}$ & $6,98 \pm 0,53^{a}$ & $\begin{array}{l}34,67 \pm 2,8 \\
5^{\mathrm{bc}}\end{array}$ & $3,72 \pm 0,9$ & $\begin{array}{l}3,13 \pm 0,1 \\
2^{\mathrm{bc}}\end{array}$ \\
\hline $\begin{array}{l}\text { TRL20 } \\
\%\end{array}$ & $\begin{array}{l}4,23 \pm 0,5 \\
4\end{array}$ & $\begin{array}{l}26,33 \pm 3,3 \\
6\end{array}$ & $\begin{array}{l}62,50 \pm 3,7 \\
4\end{array}$ & $6,66 \pm 1,06^{\mathrm{a}}$ & $\begin{array}{l}42,47 \pm 7,2 \\
0^{\text {cd }}\end{array}$ & $\begin{array}{l}3,50 \pm 0,3 \\
8\end{array}$ & $\begin{array}{l}3,51 \pm 0,2 \\
0^{\mathrm{c}}\end{array}$ \\
\hline $\begin{array}{l}\text { TRL25 } \\
\%\end{array}$ & $\begin{array}{l}4,76 \pm 0,8 \\
5\end{array}$ & $\begin{array}{l}24,91 \pm 0,7 \\
7\end{array}$ & $\begin{array}{l}62,99 \pm 0,5 \\
5\end{array}$ & $7,93 \pm 1,41^{\mathrm{b}}$ & $\begin{array}{l}50,93 \pm 4,8 \\
5^{\mathrm{d}}\end{array}$ & $\begin{array}{l}3,93 \pm 0,5 \\
1\end{array}$ & $\begin{array}{l}3,41 \pm 0,4 \\
3^{\mathrm{c}}\end{array}$ \\
\hline & $\mathrm{p}=0,882$ & $\mathrm{p}=0,244$ & $\mathrm{p}=0,360$ & $\mathrm{p}=0,038$ & $\mathrm{p}=0,000$ & $\mathrm{p}=0,826$ & $\mathrm{p}=0,000$ \\
\hline
\end{tabular}

Keterangan :Angka yang diikuti huruf superscript berbeda menunjukkan beda nyata TRL = Tepung Rumput Laut

Kadar lemak MP-ASI biskuit dengan substitusi tepung rumput laut Sargassum $s p$ berkisar antara 23,67 - 26,67\%. Formulasi tepung rumput laut Sargassum sp sebagai substitusi pembuatan MP-ASI biskuit tidak berpengaruh terhadap kadar lemak MP-ASI biskuit $(\mathrm{p}=0,244)$.

Kadar serat kasar biskuit dengan substitusi tepung rumput laut Sargassum $s p$ berkisar antara 5,04-7,93\%. Formulasi tepung rumput laut Sargassum $s p$ sebagai substitusi pembuatan MP-ASI biskuit berpengaruh terhadap kadar serat kasar $(\mathrm{p}=0,038)$.
Kadar air MP-ASI biskuit dengan substitusi tepung rumput laut Sargassum $s p$ berkisar antara 3,50 - 4,07\%. Formulasi tepung rumput laut Sargassum $s p$ sebagai substitusi pembuatan MP-ASI biskuit tidak berpengaruh terhadap kadar air MP-ASI biskuit $(\mathrm{p}=0,826)$.

Kadar abu MP-ASI biskuit dengan substitusi tepung rumput laut Sargassum $s p$ berkisar antara 2,03 - 3,51\%. Formulasi tepung rumput laut Sargassum $s p$ sebagai substitusi pembuatan MP-ASI biskuit berpengaruh terhadap kadar abu MP-ASI biskuit ( $\mathrm{p}=0,000)$. 


\section{B. Kesukaan}

Penilaian kesukaan biskuit didapatkan dengan uji hedonik yang dilakukan meliputi uji kesukaan panelis terhadap warna, aroma, rasa, dan tekstur MP-ASI biskuit. Hasil analisis dapat dilihat pada Lampiran 6 dan secara singkat disajikan pada
Tabel 2. Penilaian kesukaan terhadap warna, aroma, rasa, dan tekstur MP-ASI biskuit dengan substitusi tepung rumput laut Sargassum $s p$ berpengaruh terhadap tingkat kesukaan panelis $(\mathrm{p}=0.000)$.

Tabel 2. Hasil Analisis Penilaian Kesukaan MP-ASI biskuit dengan Substitusi Tepung Rumput Laut Sargassum $s p$

\begin{tabular}{|c|c|c|c|c|c|c|c|c|}
\hline \multirow{2}{*}{$\begin{array}{l}\text { Formul } \\
\mathrm{a}\end{array}$} & \multicolumn{2}{|l|}{ Warna } & \multicolumn{2}{|l|}{ Aroma } & \multicolumn{2}{|l|}{ Rasa } & \multicolumn{2}{|l|}{ Tekstur } \\
\hline & Rerata & Ket & Rerata & Ket & Rerata & Ket & Rerata & Ket \\
\hline $\begin{array}{l}\text { Tepung } \\
\text { RL 0\% }\end{array}$ & $\begin{array}{l}4,25 \pm 0,69 \\
\text { a }\end{array}$ & Suka & $\begin{array}{l}4,46 \pm 0,62 \\
\text { a }\end{array}$ & Suka & $\begin{array}{l}4,36 \pm 0,7 \\
0^{\mathrm{a}}\end{array}$ & Suka & $\begin{array}{l}4,37 \pm 0,6 \\
5^{\mathrm{a}}\end{array}$ & $\begin{array}{l}\text { Suk } \\
\text { a }\end{array}$ \\
\hline $\begin{array}{l}\text { Tepung } \\
\text { RL10 } \\
\%\end{array}$ & $2,85 \pm 0,88$ & $\begin{array}{l}\text { Netra } \\
1\end{array}$ & $\begin{array}{l}3,33 \pm 0,93 \\
\text { bc }\end{array}$ & $\begin{array}{l}\text { Netra } \\
1\end{array}$ & $\begin{array}{l}3,60 \pm 0,9 \\
4^{b}\end{array}$ & Suka & $\begin{array}{l}4,00 \pm 0,6 \\
9^{b}\end{array}$ & $\begin{array}{l}\text { Suk } \\
\text { a }\end{array}$ \\
\hline $\begin{array}{l}\text { Tepung } \\
\text { RL15 } \\
\%\end{array}$ & $\underset{b}{2,65 \pm 0,86}$ & $\begin{array}{l}\text { Netra } \\
1\end{array}$ & $\begin{array}{l}3,54 \pm 0,90 \\
\text { b }\end{array}$ & Suka & $\begin{array}{l}3,70 \pm 0,8 \\
8^{\mathrm{b}}\end{array}$ & Suka & $\begin{array}{l}3,77 \pm 0,7 \\
3^{\mathrm{c}}\end{array}$ & $\begin{array}{l}\text { Suk } \\
\text { a }\end{array}$ \\
\hline $\begin{array}{l}\text { Tepung } \\
\text { RL20 } \\
\%\end{array}$ & $\underset{b}{2,76 \pm 0,92}$ & $\begin{array}{l}\text { Netra } \\
1\end{array}$ & $\begin{array}{l}3,12 \pm 0,97 \\
c\end{array}$ & $\begin{array}{l}\text { Netra } \\
1\end{array}$ & $\begin{array}{l}3,30 \pm 1,0 \\
1^{\mathrm{c}}\end{array}$ & $\begin{array}{l}\text { Netr } \\
\text { al }\end{array}$ & $\begin{array}{l}3,70 \pm 0,7 \\
3^{c}\end{array}$ & $\begin{array}{l}\text { Suk } \\
\text { a }\end{array}$ \\
\hline $\begin{array}{l}\text { Tepung } \\
\text { RL25 } \\
\%\end{array}$ & $\underset{b}{2,70 \pm 1,06}$ & $\begin{array}{l}\text { Netra } \\
1\end{array}$ & $\begin{array}{l}3,14 \pm 0,84 \\
c\end{array}$ & $\begin{array}{l}\text { Netra } \\
1\end{array}$ & $\begin{array}{l}3,20 \pm 0,9 \\
3^{\mathrm{c}}\end{array}$ & $\begin{array}{l}\text { Netr } \\
\text { al }\end{array}$ & $\begin{array}{l}3,70 \pm 0,7 \\
5^{\mathrm{c}}\end{array}$ & $\begin{array}{l}\text { Suk } \\
\text { a }\end{array}$ \\
\hline & $\mathrm{p}=0.000$ & & $\mathrm{p}=0.000$ & & $\mathrm{p}=0.000$ & & $\mathrm{p}=0.000$ & \\
\hline
\end{tabular}

Keterangan : Angka yang diikuti huruf superscript berbeda menunjukkan beda nyata

Penilaian terhadap warna MP-ASI biskuit dengan substitusi tepung rumput laut Sargassum $s p$ dapat diterima oleh panelis dengan tingkat kesukaan netral terkecuali produk kontrol yang mendapat penilaian suka dari panelis. Hasil uji kesukaan terhadap aroma menunjukkan bahwa MP-ASI biskuit dengan substitusi tepung rumput laut Sargassum sp 15\% memiliki tingkat kesukaan tertinggi yakni 3,54 (suka), sedangkan ketiga formula lainnya dinilai dengan tingkat kesukaan netral. Hasil uji kesukaan rasa menunjukkan bahwa MP-ASI biskuit dengan substitusi tepung rumput laut Sargassum $s p$ memiliki tingkat kesukaan suka untuk MP-ASI biskuit kontrol dan MP-ASI dengan substitusi $10 \%$ dan $15 \%$, sedangkan MP-ASI biskuit dengan substitusi tepung rumput laut Sargassum sp 20\% dan 25\% dinilai dengan tingkat kesukaan netral. Hasil uji kesukaan tekstur menunjukkan tingkat kesukaan suka pada semua formula. Biskuit dengan substitusi tepung rumput laut Sargassum sp 10\% memiliki tingkat kesukaan tertinggi yakni 4,00 (suka).

\section{PEMBAHASAN}

\section{Kandungan Zat Gizi MP-ASI biskuit}

Berdasarkan hasil penelitian kadar zat besi MP-ASI biskuit dengan berbagai variasi substitusi tepung rumput laut Sargassum $s p$ berkisar antara 7,82 - 50,93 ppm. Berdasarkan SNI 01-7111.2-2005 persyaratan untuk kadar zat besi MP-ASI biskuit usia 12-24 bulan adalah maksimal 50,00 ppm. ${ }^{14}$ Biskuit dengan substitusi tepung rumput laut Sargassum sp 25\% sedikit melebihi persyaratan sementara variasi perlakuan yang lain memenuhi persyaratan tersebut. Variasi substitusi tepung rumput laut Sargassum $s p$ berpengaruh secara signifikan, dimana biskuit dengan substitusi tepung rumput laut Sargassum sp 25\% merupakan biskuit dengan kadar zat besi tertinggi dibandingkan dengan variasi substitusi lainnya. Hasil analisis menunjukkan semakin banyak variasi substitusi tepung rumput laut Sargassum sp maka kadar zat besi MP-ASI biskuit semakin tinggi.

Kandungan zat besi yang tinggi pada MP-ASI biskuit ini karena bahan baku pembuatan MP-ASI biskuit ini adalah rumput laut Sargassum $s p$ yang memiliki kandungan zat besi sebesar 68,2 
$\mathrm{mg} / 100 \mathrm{~g}$ dengan bioavailabilitas yang sebesar $22 \%$. $^{7}$ Persentase tersebut lebih besar dibandingkan dengan sumber zat besi non hem seperti dalam sayuran yang memiliki persentase maksimal $10 \%$. Hal ini dikarenakan tidak ditemukannya kandungan asam fitat yang mampu mengganggu absorpsi melalui pengikatan zat besi. ${ }^{9}$ Zat besi merupakan mineral mikro yang berperan penting dalam tubuh. Seorang anak yang mengalami anemia, diketahui memiliki jumlah hemoglobin yang lebih rendah. Hal ini karena zat besi merupakan mineral yang memproduksi hemoglobin. Hemoglobin berfungsi mengangkut oksigen dari paru ke jaringan tubuh, sehingga apabila jumlah hemoglobin rendah maka jumlah oksigen yang terangkut menjadi berkurang. ${ }^{9}$ Anemia defisiensi zat besi pada anak juga dapat meyebabkan peningkatan kerawanan terhadap penyakit infeksi serta berpengaruh pada kemampuan fisik dan kognitif anak. ${ }^{3,15}$

Hasil penelitian menunjukkan kadar protein MP-ASI biskuit dengan substitusi tepung rumput laut Sargassum sp berkisar antara 4,23 $4,52 \%$. Kadar protein minimal yang disyaratkan untuk MP-ASI biskuit usia 12-24 bulan menurut SNI 01-7111.2-2005 adalah 6\%. ${ }^{14}$ Hal ini menunjukkan bahwa semua formula belum memenuhi persyaratan tersebut.

Beberapa faktor yang berkaitan dengan rendahnya kadar protein dalam MP-ASI biskuit adalah, kadar protein yang ada didalam tepung rumput laut Sargassum sp rendah yakni sebesar $6,1 \%$, selain itu penggunaan tepung terigu yang digunakan merupakan tepung terigu berprotein rendah sehingga tidak mampu meningkatkan kadar protein pada MP-ASI biskuit. Pada anak-anak protein merupakan zat gizi yang dibutuhkan untuk pertumbuhan dan pembentukan jaringan tubuh. Disamping itu protein juga berperan sebagai antibodi di dalam tubuh yang melindungi tubuh dari penyakit dan sebagai zat pengangkut yang membawa zat-zat gizi. ${ }^{16}$

Hasil penelitian menunjukkan untuk kadar karbohidrat MP-ASI biskuit dengan substitusi rumput laut Saragassum $s p$ berkisar antara 62,43 - 65,35\%. Hal ini menunjukkan bahwa semua formula MP-ASI biskuit dengan substitusi tepung rumput laut Sargassum $s p$ memenuhi persyaratan SNI 01-7111.2-2005, karena syarat untuk kadar karbohidrat minimal MP-ASI biskuit usia 12-24 bulan adalah 30\%. ${ }^{14}$ Berdasarkan hasil analisis kandungan gizi tepung rumput laut, tepung rumput laut Sargassum $s p$ memiliki kadar karbohidrat yang cukup tinggi yaitu 64,65\%, sehingga berkontribusi terhadap peningkatan kadar karbohidrat

Pada proses pembuatan biskuit, proses pemanggangan berpengaruh terhadap peningkatan nilai cerna kadar karbohidrat karena proses pemanggangan menyebabkan gelatinisasi pati yang akan meningkatkan nilai cerna karbohidrat. ${ }^{17}$ Dalam produk makanan, karbohidrat berperan dalam penentuan karakteristik dari bahan makanan seperti pada warna, rasa dan tekstur. ${ }^{18}$

Hasil analisis kadar lemak MP-ASI biskuit dengan substitusi tepung rumput laut Sargassum $s p$ adalah 23,67-26,67\%. Kadar lemak pada MP-ASI biskuit berdasarkan SNI 01-7111.22005 adalah minimal $6 \%,{ }^{14}$ sehingga semua perlakuan variasi biskuit dengan substitusi tepung rumput laut Sargassum sp memenuhi persyaratan tersebut. Kadar lemak yang ada didalam biskuit berasal dari margarin dan kuning telur sebagai bahan yang berkontribusi terhadap kadar lemak MP-ASI biskuit. ${ }^{19}$

Lemak merupakan komponen penting dalam pembuatan biskuit karena beperan sebagai bahan pengemulsi sehingga produk biskuit yang dihasilkan memiliki tekstur yang renyah. ${ }^{19}$ Disamping itu, lemak juga berperan dalam pembentukan citarasa yang khas dari biskuit. ${ }^{11}$ Lemak berperan sebagai sumber asam lemak esensial. Asam lemak esensial berfungsi untuk perkembangan sistem syaraf, kecerdasan pada anak-anak. Fungsi lain dari lemak adalah sebagai pelarut vitamin A, D, E dan $\mathrm{K}$ sehingga apabila anak-anak kekurangan asupan lemak maka akan cenderung mengalami defisiensi vitamin larut lemak. ${ }^{11}$

Kadar serat kasar MP-ASI biskuit dengan substitusi tepung rumput laut Sargassum $s p$ adalah 5,94 - 7,93\%, berdasarkan SNI 01-7111.2-2005 nilai kadar serat MP-ASI biskuit lebih tinggi dibandingkan dengan yang disyaratkan yakni sebesar $5 \% .{ }^{14}$ Hal ini berkaitan dengan cukup tingginya kadar serat dari bahan utama yang digunakan yakni rumput laut. Diketahui bahwa kadar serat kasar tepung rumput laut Sargassum $s p$ pada penelitian ini adalah $14,80 \%$. Namun demikian, pada anak usia 12-24 bulan asupan serat seharusnya tidak lebih dari 5\%, hal ini berkaitan dengan terganggunya proses penyerapan zat-zat gizi didalam usus kecil serta kerja enzim-enzim pencernaan. Serat dapat memberikan rasa kenyang yang lebih cepat, sehingga jumlah zat gizi yang seharusnya dikonsumsi menjadi berkurang. ${ }^{20}$

Kadar air biskuit dengan substitusi tepung rumput laut Sargassum sp adalah 3,50- 
4,07\%. Berdasarkan SNI 01-7111.2-2005 persyaratan kadar air maksimal untuk MP-ASI biskuit usia 12-24 bulan adalah 5\%. ${ }^{14}$ Dari hasil analisis diketahui bahwa semua variasi substitusi MP-ASI biskuit memenuhi persyaratan. Kadar air berhubungan dengan daya tahan dari suatu produk makanan. Tingginya kadar air berpengaruh pada percepatan umur simpan bahan pangan sehingga memudahkan timbulnya mikroorganisme. ${ }^{19}$ Proses pemanggangan biskuit, meyebabkan terjadinya pemanasan dan pengurangan kadar air. Kadar air pada biskuit akan berpengaruh pada tekstur sehingga biskuit dengan kadar air tinggi akan cenderung tidak renyah. ${ }^{21}$

Kadar abu biskuit dengan substitusi tepung rumput laut Sargassum sp adalah 1,993,51\%. Persyaratan SNI 01-7111.2-2005 untuk kadar abu maksimal MP-ASI biskuit usia 12-24 bulan adalah 3,5\%. ${ }^{14}$ Berdasarkan hasil analisis menunjukkan bahwa kadar abu biskuit dengan substitusi tepung rumput laut Sargassum sp 20\% belum memenuhi persyaratan karena sedikit melebihi persyaratan, namun untuk variasi substitusi lainnya sudah memenuhi persyaratan tersebut. Kadar abu berkaitan dengan mineral, sehingga apabila kadar abu tepung rumput laut tinggi menunjukkan bahwa kandungan mineral didalamnya pun tinggi. ${ }^{19}$

\section{Kesukaan}

Warna biskuit yang dihasilkan pada beberapa variasi substitusi tepung rumput laut Sargassum $s p$ memiliki tingkat penilaian netral yakni antara 2,65 - 2,85 terkecuali pada biskuit kontrol dapat diterima dengan tingkat penilaian suka. Hal ini dapat disebabkan karena warna biskuit yang dihasilkan hampir sama untuk tiap variasi substitusi, seperti yang ditunjukkan pada Gambar 2 sehingga panelis sulit membedakan dengan jelas warna pada biskuit.

Formulasi MP-ASI biskuit dengan substitusi tepung rumput laut Sargassum $s p$ menghasilkan warna coklat, semakin banyak jumlah substitusi tepung rumput laut Sargassum $s p$ maka semakin gelap warna coklat yang dihasilkan. Warna coklat yang dihasilkan berasal dari tepung rumput laut yang disubstitusikan ke dalam biskuit dimana karakter warna tepung rumput laut Sargassum sp adalah coklat tua. Rumput laut Sargassum sp dan tepung rumput laut Sargassum $s p$ dapat dilihat pada Gambar 1 .

Penilaian panelis terhadap aroma MP-ASI biskuit dengan substitusi tepung rumput laut Sargassum $s p$ dinilai dengan tingkat kesukaan netral untuk biskuit dengan substitusi tepung rumput laut Sargassum sp 10\%, 20\% dan 25\% dengan rerata nilai antara 3,12 - 3,33 sementara untuk biskuit dengan substitusi tepung rumput laut Sargassum sp $15 \%$ dan kontrol dinilai suka oleh panelis.

Aroma yang dihasilkan MP-ASI biskuit adalah sedikit amis. Hal ini berkenaan dengan bahan baku yakni tepung rumput laut yang memiliki aroma agak amis. Namun demikian aroma amis tersebut dapat ditutupi dengan aroma margarin yang menghasilkan aroma gurih sehingga aroma MP-ASI biskuit masih dapat diterima oleh panelis. Semakin banyak substitusi tepung rumput laut Sargassum $s p$ semakin rendah pula tingkat penerimaan terhadap MP-ASI biskuit.

Berdasarkan penilaian uji hedonik terhadap rasa MP-ASI biskuit dengan substitusi tepung rumput laut Sargassum sp tingkat kesukaan panelis terhadap rasa berkisar antara 3,20 - 3,70 dimulai dari netral sampai suka. MP-ASI biskuit dengan substitusi tepung rumput laut Sargassum $s p$ memiliki rasa manis dan gurih. Berdasarkan hasil analisis nilai rerata MP-ASI biskuit dengan substitusi tepung rumput laut Sargassum $s p$ jika dibandingkan dengan biskuit kontrol nilainya sedikit lebih rendah. Hal ini berkaitan dengan penambahan tepung rumput laut didalamnya, sehingga membuat rasanya sedikit kurang manis.

Penilaian terhadap tekstur merupakan penilaian utama pada produk biskuit. Tekstur biskuit yang diharapkan adalah biskuit dengan tekstur renyah namun lembut pada saat diseduh air. ${ }^{4}$ Pada MP-ASI biskuit dengan substitusi tepung rumput laut Sargassum sp tingkat kesukaan panelis terhadap tekstur berkisar antara 3,70-4,00 yang diartikan semua biskuit dapat dinilai suka oleh panelis. Bila dianalisis berdasarkan statistik bahwa semakin banyak substitusi tepung rumput laut Sargassum $s p$ maka penilaian terhadap tekstur biskuit menjadi lebih rendah. Hal ini berkaitan dengan tekstur tepung rumput laut Sargassum $s p$ memiliki karakter agak kasar dan butiran sedikit terasa (grainy) selain itu karena kandungan serat yang cukup tinggi pada rumput laut sehingga berpengaruh pada kerenyahan tekstur. ${ }^{10}$

\section{Kontribusi MP-ASI biskuit Terhadap Zat Gizi}

MP-ASI biskuit dengan substitusi tepung rumput laut Sargassum $s p$ yang direkomendasikan sebagai salah satu alternatif konsumsi MP-ASI biskuit kaya zat besi untuk anak usia 12-24 bulan adalah MP-ASI biskuit dengan substitusi tepung rumput laut Sargassum sp 25\%. Hal ini karena biskuit dengan substitusi tersebut memberikan 
sumbangan zat besi yang paling baik dan masih dapat diterima panelis.

Tabel 3. Rekapitulasi Kandungan Gizi

\begin{tabular}{llllll}
\hline & TRL0\% & TRL10\% & TRL15\% & TRL20\% & TRL25\% \\
\hline $\begin{array}{l}\text { Kandungan } \\
\text { gizi }\end{array}$ & zat & & & & \\
Zat besi (ppm) & 7,82 & 25,94 & 34,67 & 42,47 & 50,93 \\
Protein (\%) & 4,34 & 4,44 & 4,52 & 4,23 & 4,76 \\
Karbohidrat (\%) & 63,40 & 65,35 & 62,43 & 62,50 & 62,99 \\
Lemak (\%) & 26,67 & 23,67 & 26,18 & 26,33 & 24,91 \\
Serat kasar (\%) & 5,04 & 6,45 & 6,98 & 6,66 & 7,93 \\
\hline
\end{tabular}

Keterangan : TRL adalah Tepung Rumput Laut

Penentuan takaran saji biskuit didasarkan pada pemenuhan 20\% dari Recommenden Dietary Allowence (RDA) kebutuhan protein ${ }^{22}$,dimana kecukupan protein anak usia 12-24 bulan adalah 13 $\mathrm{g}$, sehingga diperoleh takaran saji sebesar $55 \mathrm{~g}$. Diketahui berat satu keping biskuit adalah 15 gram, sehingga satu takaran saji dapat mengkonsumsi 4 keping biskuit dalam satu hari dengan frekuensi dua kali makan. Berdasarkan hasil perhitungan satu takaran saji MP-ASI biskuit dengan substitusi tepung rumput laut Sargassum $s p$ $25 \%$ berkontribusi terhadap pemenuhan zat besi pada anak sebesar 39,28\%.

\section{SIMPULAN DAN SARAN}

\section{A. Simpulan}

1. Substitusi tepung rumput laut
Sargassum sp berpengaruh secara bermakna terhadap peningkatan kadar zat besi, kadar serat kasar dan kadar abu MP-ASI biskuit, sedangkan untuk kadar protein, karbohidrat, lemak dan air tidak berpengaruh terhadap MP-ASI biskuit

2. MP-ASI biskuit direkomendasikan adalah biskuit dengan substitusi $25 \%$ yang berkontribusi terhadap pemenuhan zat besi pada anak sebesar $42,14 \%$.

3. Penilaian kesukaan MP-ASI biskuit dengan substitusi tepung rumput laut Sargassum $s p$ meliputi warna, aroma, rasa dan tekstur masih dapat diterima oleh panelis.

4. MP-ASI biskuit dengan substitusi tepung rumput laut Sargassum $s p$ belum memenuhi standar mutu berdasarkan SNI 01-7111.2-2005 untuk kadar protein dan serat kasar.

\section{B. Saran}

1. Perlu dilakukan penanganan untuk peningkatan kualitas sensori kesukaan biskuit seperti mengurangi aroma amis yang terdapat pada rumput laut seperti menambahkan vanili, dan menambahkan perasa coklat alami sehingga dapat lebih diterima panelis.

\section{DAFTAR PUSTAKA}

1. Querioz SS, Marco A.de A Torres. Iron deficiency in children.journal de pediatria.2000

2. Semba DR, Regina Moench-Pfanner, Kai Sun et al. Iron Fortified milk and noodle consumption is associated with lower risk of anemia among children aged 6-59 months in Indonesia. The American Journal of Clinical Nutrition.2010

3. Wahyuni AS.Anemia defisiensi pada balita.[digital library] Sumatera Utara: USU;2004 [diakses : 12 April 2012]

4. Menteri Kesehatan Republik Indonesia. keputusan menteri kesehatan republik Indonesia Nomor 224/Menkes/SK/II/2007.Spesifikasi Teknis Makanan Pendamping Air Susu Ibu (MP-ASI). Jakarta:2007

5. Rosmawaty P.Pengolahan rumput laut skala rumah tangga.Badan penelitian dan Pengembangan Kelautan dan Perikanan Kementrian Kelautan dan Perikanan. Kendari: 2011 [diakses: 12 Mei 2012]

6. Norziah $\mathrm{MH}$, Chio Yen Ching. Nutrition Compositition of Edible Seaweed Gracilaria changgi. Food Chemistry.2000.69-76 available from

7. Matanjun P, Suhaila M, Noordin M, Kharidah M. Nutrient Content of Tropical Edible Seaweeds,Euchema cotonii, Caulerpa lentillifera and Sargassum polycystum. J Appl Phycol. 2009

8. Gracia-Casal,MN,Ana CP,Irene L,Jose R,Maria FQ.High iron content and bioavailability in humans from four species of marine algae.The Journal of Nutrition.2007 J.Nutr.137:2691-2695

9. Mahan L.Kathleen and Sylvia, EscottStump.Krause's food and Nutrition Theraphy.12 ${ }^{\text {th }}$ ed. Canada:Saunders.2009.p.116$117 ; 811$

10. Chaidir A.Kajian Rumput Laut Sebagai Sumber Serat Alternatif untuk Minuman Berserat.[Tesis].Sekolah Pasca Sarjana Institut 
Pertanian Bogor (IPB). Bogor: 2004 [diakses : 8 Maret 2012]

11. Ria S. Kajian dekstrinisasi pati garut dan gelatinisasi tepung terigu untuk pengembangan Makanan Pendamping Air Susu Ibu (MP-ASI) dan Makanan Sapihan.[Tesis].Program Studi Ilmu Pangan.Bogor:IPB.2002 [diakses:21 Mei 2012]

12. Association of Analytical Chemist [AOAC] Publisher.2005.Official Methodes of Analysis of the Assocation of Official Analytical Chemist.Arlington Virginia USA:The Association of Official Analytical Chemist,Inc.

13. Dwi S, Anton A, Maya PS. Analisis sensori untuk industri pangan dan agro.Bogor:IPB Press.2010

14. Badan Standarisasi Nasional (BSN). SNI 017111.2-2005 Makanan Pendamping Air Susu Ibu (MP-ASI)-Bagian 2:Biskuit. 2005

15. Batra J,Archana S. Iron deficiency anemia:effect on cognitive development in children.Indian Journal of Clinical Biochemistry.2005 20(2) 119-125

16. Whitney E ,Sharon RR.Understanding Nutrition. $1^{\text {1th }}$ ed.United States of America:Thomson.2008

17. Palupi NS, Zakaria FR, Prangdimurti. Pengaruh Pengolahan terhadap Nilai Gizi Pangan. Modul eLearning ENBP. Bogor: Institut Pertanian Bogor (IPB). 2007 [diakses: 13 September 2012]

18. Winarno F.G. Kimia Pangan dan Gizi. Jakarta: PT Gramedia Pustaka Utama.1992

19. Cahyana S. Suplementasi tepung rumput laut Euchema cotonii pada pembuatan roti tawar dan cookies. [Skripsi]. Teknologi Pertanian. Bogor:IPB.2004 [diakses : 29 Mei 2012]

20. Deddy Muchtadi. Food Review. "Karbohidrat dalam Makanan Bayi”.Vol.1 No.3. April.Bogor.2006 [diakses : 17 September 2012]

21. Mervina.Formulasi biskuit dengan substitusi tepung ikan lele dumbo (clarias gariepinus) dan isolat protein kedelai (glycine max) sebagai makanan potensial untuk anak balita gizi kurang.[Skripsi] Gizi Mayarakat Fakultas Ekologi Manusia. Bogor:Institut Pertanian Bogor (IPB).2009 [diakses : 17 Mei 2012]

22. LIPI. Widya Karya Pangan Nasional Pangan dan Gizi VIII. Jakarta: Lembaga Ilmu Pengetahuan Indonesia.2004 